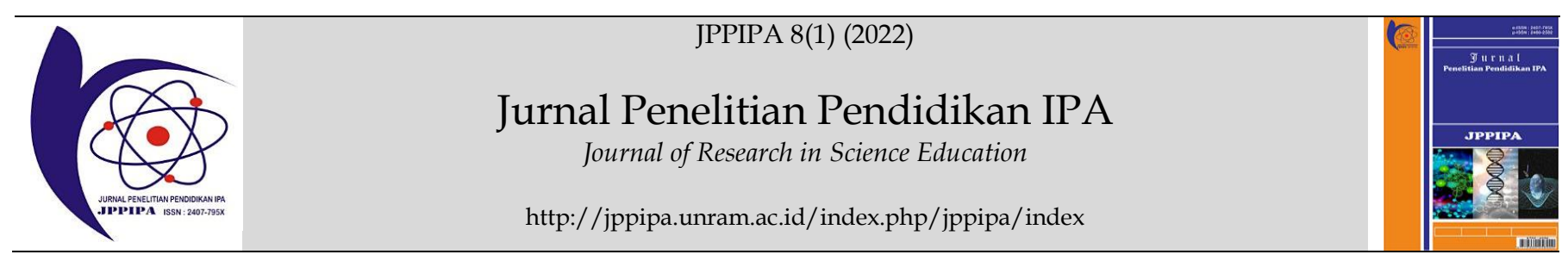

\title{
Students' Metacognitive Awareness in Natural Science Learning: An Overview by Gender
}

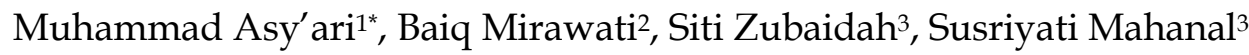 \\ ${ }^{1}$ Physics Education Department, Universitas Pendidikan Mandalika, Mataram, Indonesia. \\ ${ }^{2}$ Biology Education Department, Universitas Pendidikan Mandalika, Mataram, Indonesia \\ ${ }^{3}$ Biology Department, Universitas Negeri Malang, Malang, Indonesia \\ DOI: $\underline{10.29303 / j p p i p a . v 8 i 1.1146}$
}

\section{Article Info}

Received: November 19, 2021

Revised: December 27, 2021

Accepted: January 5, 2022

Published: Januari 31, 2022

\begin{abstract}
This study aimed to identify the metacognitive awareness of high school students in natural science learning based on gender. This research is a descriptive study with a sample of 24 students. Data on students' metacognition awareness was collected using the Metacognition Awareness Inventory (MAI) which was analyzed descriptively and statistically. The results showed that students' metacognitive awareness was categorized as good enough $(1.33<\mathrm{MA} \leq 2.33)$ and low (MA $\geq 1.33)$. Students' metacognition awareness was not significantly different in terms of gender $(p>0.05)$. Based on the results of the study, it can be concluded that metacognitive awareness needs to be improved through good interventions in learning. Student gender differences need to be investigated further using a larger sample to obtain more relevant and comprehensive data on metacognitive awareness.
\end{abstract}

Keywords: Metacognition; Metacognitive awareness; Gender, Natural science learning

\section{Citation: $\quad$ Asy'ari, M., Mirawati, B., Zubaidah, S., \& Mahanal, S. (2022). Students' Metacognitive Awareness in Natural Science Learning: An Overview by Gender. Jurnal Penelitian Pendidikan IPA, 8(1), 67-72. https://doi.org/10.29303/jppipa.v8i1.1146}

\section{Introduction}

Metacognition is often associated with intelligence that occurs in one's thinking system (Song, et al., 2021). Metacognition refers to one's ability to reflect on perceptions, knowledge, and behavior (Sternberg, 2018; Valk, et al., 2016) so that in simple terms, it is often defined as thinking about thinking or knowledge about knowledge. (Lai, 2011; Muhali, et al., 2019), which in the practical context of learning is believed to be able to guide students in developing and choosing strategies to improve cognitive performance (Margaret, 2002). Metacognition in general consists of two components, namely metacognitive knowledge and metacognitive awareness (Schraw, et al., 2012; Veenman, 2012). This study focuses on the behavioral domain of metacognition, namely metacognitive awareness which is thought control and learning activities (Schraw, et al., 2006, 2012; Schraw \& Dennison, 1994) that have three core indicators in cognitive regulation (Schraw, et al.,
2012) namely planning, monitoring, and evaluation. In its development, experts state that monitoring, when faced with real conditions, is important (Pressley \& Harris, 2009), so that information management and debugging components also need to be considered (Schraw, et al., 2012).

The results of previous studies showed that students' metacognitive awareness in 4 (four) schools in the Central Lombok region showed $6.15 \%$ in the very good category; $32.31 \%$ in a good category; $51.15 \%$ is categorized as good enough, $10.39 \%$ is in the poor category. The students' overall metacognitive awareness on each indicator was in the poor category with an average percentage of students' metacognition awareness of $35.66 \%$. These results illustrate that teachers have difficulty directing the student learning process and it takes a long time to train students' metacognitive awareness (Sukaisih \& Muhali, 2014). Students have low metacognitive awareness and affect students' motivation and attitudes in learning so that 
metacognition becomes a learning goal that must be taught, especially in the categories of cognitive monitoring, cognitive regulation, and cognitive monitoring and regulation (Tosun \& Senocak, 2013).

At different levels, research has been conducted on 820 elementary school teachers. The results of this study indicate that the metacognitive strategies that are often used are cognitive strategies, self-evaluation, and self-awareness. Significant differences were found in metacognition strategies based on gender, grade, and university origin. Meanwhile, based on a review of the differences in learning outcomes and the metacognition strategies used, no significant differences were found (Belet \& Guven, 2011). On the other hand, it was found that the functions of the metacognitive strategy applied in learning were the dominant predictors of academic self-efficacy (Alt, 2015). It was further explained that metacognition and reflective activities help students stay focused and motivated to learn (Karaali, 2015) so it is believed that at all ages and levels of education it is very important to learn (Jaleel \& P., 2016).

Gender is believed to have a correlation with thinking skills (Aliakbari \& Sadeghdaghighi, 2011; Harish, 2015; Mahanal, et al., 2017). Gender is a general term that refers to men and women (Fin \& Ishak, 2012; Mahanal, et al., 2017) that shape a person's psychology and social roles (Fuad et al., 2017) so that it has an impact on how individuals think, behave, and act. and feel a phenomenon within (Santrock, 2011). Based on this description, men and women can differ in the context of thinking skills and thinking disposition, men in thinking are more analytical and flexible than women, while women are less proficient in abstract and logical thinking (Kruteckij \& Kruteckij, 1976). Men and women do not have differences in understanding concepts, but men are superior in problem-solving than women (Gok, 2014). On the other hand, it was found that there was no significant correlation of thinking skills between men and women (Taghva, et al., 2014).

Based on this description, there are still differences of opinion regarding the role of gender in student learning outcomes, especially on the component of students' metacognitive awareness. Some studies that are in accordance with students' metacognitive awareness have been frequently reported. Students often predict their exam score based on their desire score (Saenz et al., 2017), but in fact, their predictions are often strongly correlated with their desire score than their exam score (Serra \& DeMarree, 2016) that showed the lack of students' metacognitive awareness (Morphew, 2021). Moreover, Sk and Halder (2020) describe that the affective domain (including metacognitive awareness) facilitated students to use appropriate strategies to solve a specific problem and found no significant difference between males and females. In contrast, (Abdelrahman,
2020) found females strongly higher levels than males on metacognitive awareness. However, this research was conducted in university (Abdelrahman, 2020; Morphew, 2021; Sk \& Halder, 2020) and senior high school (Saenz et al., 2017; Serra \& DeMarree, 2016) students. Research by Liliana and Lavinia (2011) that conducted on the 8thgrade students (junior high school) found females and male students' metacognitive awareness was significantly different on different metacognitive awareness in comparison with the current study namely: perceptions of performances, teacher expectations, problem-solving, planning, cognitive strength and weaknesses, and monitoring.

This study aimed to identify the metacognitive awareness of junior high school students in natural science learning based on gender. Metacognition awareness in this study has eight components, namely declarative knowledge, procedural knowledge, conditional knowledge, planning, monitoring, information management system, debugging, and evaluation.

\section{Method}

This research is a descriptive study with 24 students (13 male and 11 female) grade VII at one of the secondary schools in North Lombok as the research sample. Data on students' metacognition awareness was collected using the Metacognition Awareness Inventory (MAI) developed by Schraw and Dennison (1994). MAI is empirically declared valid and reliable (Asy'ari et al., 2018; Feiz, 2016) for an inventory of students' metacognitive awareness.

Students' metacognition awareness was descriptively calculated using Equation 1 and the scores obtained were then converted into four categories as shown in Table 1.

Metacognition Awareness $=\frac{\text { Score obtained }}{\text { maximum score }} \times 4$

Table 1. Students' Metacognition Awareness categories (Asy'ari et al., 2019).

\begin{tabular}{ll}
\hline Score interval & Category \\
\hline $3.33<\mathrm{MA} \leq 4.00$ & Very good \\
$2.33<\mathrm{MA} \leq 3.33$ & Good \\
$1.33<\mathrm{MA} \leq 2.33$ & Good enough \\
$\mathrm{MA} \geq 1.33$ & Low \\
\hline
\end{tabular}

Inferential analysis was used to identify differences in students' metacognitive awareness based on gender. Prerequisite tests were also carried out in this study using IBM SPSS Statistics 23 software. 


\section{Result and Discussion}

Students' metacognitive awareness was descriptively analyzed and categorized based on the criteria described previously. The results of the descriptive test of students' metacognition awareness are presented in Table 1.

Table 1. Categories of students' metacognitive awareness

\begin{tabular}{lll}
\hline Category & Score & Percentage $(\%)$ \\
\hline Very Good & $3.33<\mathrm{MA} \leq 4.00$ & 0 \\
Good & $2.33<\mathrm{MA} \leq 3.33$ & 0 \\
Good Enough & $1.33<\mathrm{MA} \leq 2.33$ & 75 \\
Low & $\mathrm{MA} \leq 1.33$ & 25 \\
\hline
\end{tabular}

Based on the results of the descriptive analysis as presented in Table 1 , it is known that students' metacognitive awareness is categorized as good enough $(75 \%)$ and low (25\%). These results indicate that it is important to carry out learning interventions to develop students' metacognitive awareness. The statement is also supported by empirical findings as long as MAI is filled out by students (Figure 1 and Figure 2). Male and female students frequently asked for the meaning of some item in the MAI that indicates the learning process may not integrate metacognitive awareness components into learning activities.

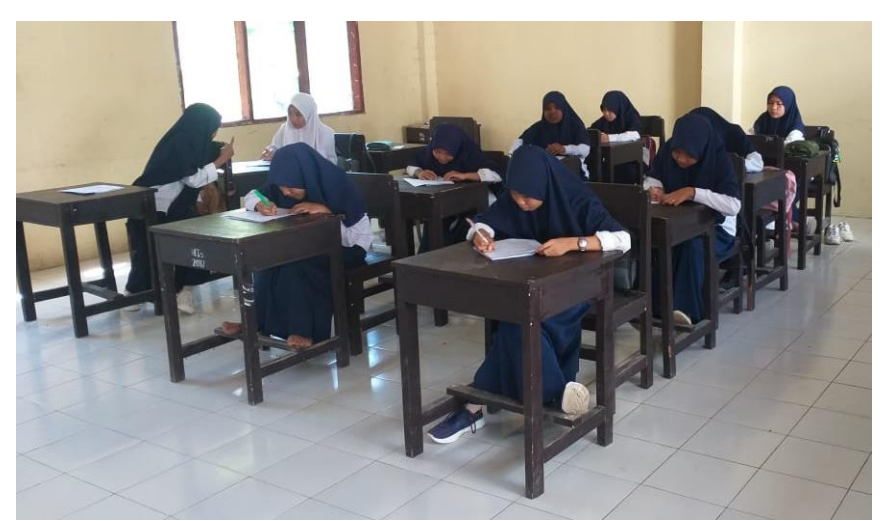

Figure 1. Female students filled out the MAI

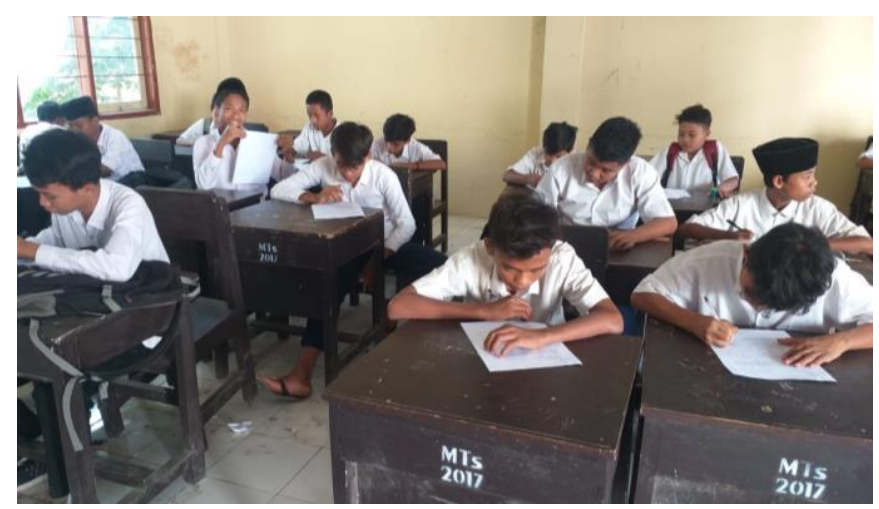

Figure 2. Male students filled out the MAI
Prerequisite analysis of students' metacognitive awareness data using the Kolmogorov-Smirnov test was carried out in this study to determine the normality of the data. The results of students' metacognitive awareness data normality test are presented in Table 2.

Table 2. The results of the normality test of students' metacognitive awareness data.

\begin{tabular}{llll}
\hline \multirow{2}{*}{ Gender } & \multirow{2}{*}{$\mathrm{N}$} & \multicolumn{2}{l}{ Metacognitive awareness } \\
\cline { 3 - 4 } & & Sig. (2-tailed) & Normality \\
\hline Male & 13 & 0.918 & Yes \\
Female & 11 & 0.876 & Yes \\
\hline
\end{tabular}

Based on Table 2, it is known that students' metacognitive awareness is normally distributed so that the parametric statistical test, namely the t-test, was conducted to determine the difference in metacognitive awareness between male and female students. The results of the students' metacognition awareness t-test are presented in Table 3.

Table 3. The results of the students' metacognitive awareness t-test

\begin{tabular}{lll}
\hline Gender & $\mathrm{N}$ & $\mathrm{p}$ \\
\hline Male & 13 & 0.998 \\
Female & 11 & \\
\hline
\end{tabular}

Table 3 shows that students' metacognitive awareness was not significantly different ( $p>0.05)$. These results indicate that students' gender has no effect on students' metacognitive awareness. The results showed that students' metacognitive awareness in general needed to be improved.

There is a correlation between metacognition and cognition with metacognition $(17 \%)$ contributing more than cognition $(10 \%)$ in causing variations in student learning of different ages and backgrounds for different types of tasks and different domains (Veenman et al., 2004; Veenman \& Spaans, 2005). Cognition focuses on problem-solving, while metacognition on the problemsolving process, as well as knowledge of how to use thinking and strategies, knowledge of how much one can learn, and what types of strategies to use (Weinert \& Kluwe, 1987). The implication is that an adequate level of metacognitive ability can compensate for students' cognitive limitations.

The empirical phenomenon that only emphasizes the cognitive aspect (product indicators) which is reflected in the criteria for the national exam questions in Indonesia is allegedly the cause of the low students' metacognitive awareness (Muhali, et al., 2020). On the other hand, Tosun and Senocak (2013) confirm the statement that in general students have low 
metacognitive awareness and have an effect on students' motivation and attitudes in learning. Metacognition is oriented to mental processes and plays a role in the system of the mind (National Research Council, 2012). Metacognition in learning should be focused on constructing knowledge through a rational relationship between the authentic experience and the material being studied (Herscovitz et al., 2012).

Students' metacognition awareness is not influenced by their gender. Taghva et al (2014) mention that there is no significant correlation of thinking skills between males and females. In contrast to this opinion, in general, females get higher scores than males on tests of verbal abilities, such as assessing reading, vocabulary, writing, grammar, and understanding from a cognitive perspective. Male get higher scores than females on visuospatial tests such as tasks that require them to change mental activity, assess the speed of moving objects, the trajectory of moving objects in threedimensional space, success in moving or moving immovable objects (Gurian \& Stevens, 2005; Halpern, 2014; Nordvik \& Amponsah, 1998; Ruble, et al., 2007). Based on this description, it can be concluded that gender is a different role in social construction, mentality, and level of thinking based on male and female gender.

\section{Conclusion}

Based on the results of the study, it can be concluded that students' metacognitive awareness needs to be improved. The gender of students has no effect on their metacognitive awareness, although many research results mention the influence of gender on a person's cognitive. Learning interventions to facilitate students in developing metacognitive awareness need to be carried out through the application of relevant learning models, authentic learning tools, and appropriate and continuous learning assessments.

\section{Acknowledgments}

Acknowledgments are conveyed to the Deputy for Strengthening Research and Development at the Ministry of Research and Technology/BRIN for their support in completing this research (Degree Number: 11/E1/KPT/2021).

\section{References}

Abdelrahman, R.M. (2020). Metacognitive awareness and academic motivation and their impact on academic achievement of Ajman University students. Heliyon, 6(9), e04192. https://doi.org/10.1016/j.heliyon.2020.e04192
Aliakbari, M., \& Sadeghdaghighi, A. (2011). Investigation of the Relationship between Gender, Field of Study, and Critical Thinking Skill: The Case of Iranian Students. Proceedings of the 16th Conference of Pan-Pacific Association of Applied Linguistics, 301-310.

Alt, D. (2015). Assessing the Contribution of a Constructivist Learning Environment to Academic Self-Efficacy in Higher Education. Learning Environments Research, 18(1), 47-67. https://doi.org/10.1007/s10984-015-9174-5

Asy'ari, M., Ikhsan, M., \& Muhali, M. (2018). Validitas Instrumen Karakterisasi Kemampuan Metakognisi Mahasiswa Calon Guru Fisika. Prisma Sains: Jurnal Pengkajian Ilmu Dan Pembelajaran Matematika Dan IPA IKIP Mataram, 6(1), 18. https://doi.org/10.33394/j-ps.v6i1.955

Asy'ari, M., Ikhsan, M., \& Muhali, M. (2019). The Effectiveness of Inquiry Learning Model in Improving Prospective Teachers' Metacognition Knowledge and Metacognition Awareness. International Journal of Instruction, 12(2), 455-470. https://doi.org/10.29333/iji.2019.12229a

Belet, S. D., \& Guven, M. (2011). Meta-Cognitive Strategy Usage and Epistemological Beliefs of Primary School Teacher Trainees. Educational Sciences: Theory and Practice, 11(1), 51-57.

Feiz, J.P. (2016). Metacognitive Awareness and Attitudes toward Foreign Language Learning in the EFL Context of Turkey. Procedia - Social and Behavioral Sciences, 232, 459-470. https://doi.org/10.1016/j.sbspro.2016.10.063

Fin, L. S., \& Ishak, Z. (2012). A Priori Model of Students' Academic Achievement: The Effect of Gender as Moderator. Procedia - Social and Behavioral Sciences, 65 , 1092-1100. https://doi.org/10.1016/j.sbspro.2013.02.122

Fuad, N.M., Zubaidah, S., Mahanal, S., \& Suarsini, E. (2017). Improving Junior High Schools' Critical Thinking Skills Based on Test Three Different Models of Learning. International Journal of Instruction, 10(01), 101-116. https://doi.org/10.12973/iji.2017.1017a

Gok, T. (2014). Peer instruction in the physics classroom: Effects on gender difference performance, conceptual learning, and problem-solving. Journal of Baltic Science Education, 13(6), 776-788. https://doi.org/10.33225/jbse/14.13.776

Gurian, M., \& Stevens, K. (2005). The minds of boys: Saving our sons from falling behind in school and life. JosseyBass.

Halpern, D.F. (2014). Thought and Knowledge: An Introduction to Critical Thinking. Psycology Press. Retrieved 
https://www.routledge.com/Thought-and$\ldots 291$

Harish, G.C. (2015). Critical Thinking Skills among Ninth Standard Students in Relation to Gender, Intelligence and Study habits. International Journal of Education and Psychological Research, 2(3), 12-20.

Herscovitz, O., Kaberman, Z., Saar, L., \& Dori, Y. (2012). The Relationship Between Metacognition and the Ability to Pose Questions in Chemical Education (pp. 165-195). https://doi.org/10.1007/978-94-0072132-6_8

Jaleel, S., \& P., P. (2016). A Study on the Metacognitive Awareness of Secondary School Students. Universal Journal of Educational Research, 4(1), 165172. https://doi.org/10.13189/ujer.2016.040121

Karaali, G. (2015). Metacognition in the Classroom: Motivation and Self-Awareness of Mathematics Learners. PRIMUS, 25(5), 439-452. https://doi.org/10.1080/10511970.2015.1027837

Kruteckij, V. A., \& Kruteckij, V. A. (1976). The psychology of mathematical abilities in schoolchildren. Univ. of Chicago Press.

Lai, E. R. (2011). Metacognition: A literature review (pp. 141). Pearson's Research Reports. Retrieved from: https://images.pearsonassessments.com/images $\angle$ tmrs/..._Final.pdf

Liliana, C., \& Lavinia, H. (2011). Gender Differences in Metacognitive Skills. A Study of the 8th Grade Pupils in Romania. Procedia - Social and Behavioral Sciences, 29, 396-401. https://doi.org/10.1016/j.sbspro.2011.11.255

Mahanal, S., Tendrita, M., Ramadhan, F., Ismirawati, N., \& Zubaidah, S. (2017). The Analysis of Students' Critical Thinking Skills on Biology Subject. Anatolian Journal of Instruction, 2(2), 21-39. Retrieved https:/ / eric.ed.gov/?id=EJ1244660

Margaret, M., W. (2002). Metacognition. Thomson Learning, Inc.

Morphew, J. W. (2021). Changes in metacognitive monitoring accuracy in an introductory physics course. Metacognition and Learning, 16(1), 89-111. https://doi.org/10.1007/s11409-020-09239-3

Muhali, M., Asy'ari, M., \& Sukaisih, R. (2020). Analisis Kemampuan Regulasi Kognisi Peserta Didik dalam Pembelajaran. Empiricism Journal, 1(2), 5159. https://doi.org/10.36312/ej.v1i2.333

Muhali, M., Yuanita, L., \& Ibrahim, M. (2019). The Validity and Effectiveness of the ReflectiveMetacognitive Learning Model to Improve Students' Metacognition Ability in Indonesia. Malaysian Journal of Learning and Instruction, 16(2), 33-74. https://doi.org/10.32890/mjli2019.16.2.2

National Research Council (Ed.). (2012). A framework for K-12 science education: Practices, crosscutting concepts, and core ideas. The National Academies Press.

Nordvik, H., \& Amponsah, B. (1998). Gender differences in spatial abilities and spatial activity among university students in an egalitarian educational system. Sex Roles: A Journal of Research, 38(11-12), 1009-1023.

https://doi.org/10.1023/A:1018878610405

Pressley, M., \& Harris, K. R. (2009). Cognitive Strategies Instruction: From Basic Research to Classroom Instruction. Journal of Education, 189(1-2), 77-94. https://doi.org/10.1177/0022057409189001-206

Ruble, D. N., Martin, C. L., \& Berenbaum, S. A. (2007). Gender Development. In W. Damon \& R. M. Lerner (Eds.), Handbook of Child Psychology (p. chpsy0314). John Wiley \& Sons, Inc. https://doi.org/10.1002/9780470147658.chpsy03 $\underline{14}$

Saenz, G. D., Geraci, L., Miller, T. M., \& Tirso, R. (2017). Metacognition in the classroom: The association between students' exam predictions and their desired grades. Consciousness and Cognition, 51, 125-139.

https://doi.org/10.1016/j.concog.2017.03.002

Santrock, J. W. (2011). Educational psychology (5th ed). McGraw-Hill.

Schraw, G., Crippen, K. J., \& Hartley, K. (2006). Promoting Self-Regulation in Science Education: Metacognition as Part of a Broader Perspective on Learning. Research in Science Education, 36(1-2), 111-139. $\quad$ https://doi.org/10.1007/s11165-005$3917-8$

Schraw, G., \& Dennison, R. S. (1994). Assessing Metacognitive Awareness. Contemporary Educational Psychology, 19(4), 460-475. https://doi.org/10.1006/ceps.1994.1033

Schraw, G., Olafson, L., Weibel, M., \& Sewing, D. (2012). Metacognitive Knowledge and Field-based Science Learning in an Outdoor Environmental Education Program. In A. Zohar \& Y. J. Dori (Eds.), Metacognition in Science Education: Trends in Current Research. Springer Netherlands. https://doi.org/10.1007/978-94-007-2132-6

Serra, M. J., \& DeMarree, K. G. (2016). Unskilled and unaware in the classroom: College students' desired grades predict their biased grade predictions. Memory \& Cognition, 44(7), 1127-1137. https://doi.org/10.3758/s13421-016-0624-9

Sk, S., \& Halder, S. (2020). Critical thinking disposition of undergraduate students in relation to emotional intelligence: Gender as a moderator. Heliyon, 6(11), e05477. https://doi.org/10.1016/j.heliyon.2020.e05477

Song, J. H. H., Loyal, S., \& Lond, B. (2021). Metacognitive Awareness Scale, Domain Specific (MCAS-DS): 
Assessing Metacognitive Awareness During Raven's Progressive Matrices. Frontiers in Psychology, 11, 3683. https://doi.org/10.3389/fpsyg.2020.607577

Sternberg, R. J. (2018). Theories of intelligence. In S. I. Pfeiffer, E. Shaunessy-Dedrick, \& M. FoleyNicpon (Eds.), APA handbook of giftedness and talent. (pp. 145-161). American Psychological Association. https://doi.org/10.1037/0000038$\underline{010}$

Sukaisih, R., \& Muhali, M. (2014). Meningkatkan Kesadaran Metakognitif dan Hasil Belajar Siswa Melalui Penerapan Pembelajaran Problem Solving. Prisma Sains : Jurnal Pengkajian Ilmu Dan Pembelajaran Matematika Dan IPA IKIP Mataram, 2(1), 71. https://doi.org/10.33394/j-ps.v2i1.803

Taghva, F., Rezaei, N., Ghaderi, J., \& Taghva, R. (2014). Studying the Relationship between Critical Thinking Skills and Students' Educational Achievement (Eghlid Universities as Case Study). International Letters of Social and Humanistic Sciences, 25, 18-25. https://doi.org/10.18052/www.scipress.com/IL SHS.25.18

Tosun, C., \& Senocak, E. (2013). The Effects of ProblemBased Learning on Metacognitive Awareness and Attitudes toward Chemistry of Prospective Teachers with Different Academic Backgrounds. Australian Journal of Teacher Education, 38(3). https://doi.org/10.14221/ajte.2013v38n3.2

Valk, S. L., Bernhardt, B. C., Böckler, A., Kanske, P., \& Singer, T. (2016). Substrates of metacognition on perception and metacognition on higher-order cognition relate to different subsystems of the mentalizing network: Multimodal MRI Studies of Metacognition. Human Brain Mapping, 37(10), 3388-3399. https:// doi.org/10.1002/hbm.23247

Veenman, M. V. J. (2012). Metacognition in Science Education: Defi nitions, Constituents, and Their Intricate Relation with Cognition. In A. Zohar \& Y. J. Dori (Eds.), Metacognition in Science Education (Vol. 40, pp. 21-36). Springer Netherlands. https://doi.org/10.1007/978-94-007-2132-6_2

Veenman, M. V. J., \& Spaans, M. A. (2005). Relation between intellectual and metacognitive skills: Age and task differences. Learning and Individual Differences, 15(2), 159-176. https:// doi.org/10.1016/j.lindif.2004.12.001

Veenman, M. V. J., Wilhelm, P., \& Beishuizen, J. J. (2004). The relation between intellectual and metacognitive skills from a developmental perspective. Learning and Instruction, 14(1), 89109.

https://doi.org/10.1016/j.learninstruc.2003.10.0 $\underline{04}$
Weinert, F. E., \& Kluwe, R. (Eds.). (1987). Metacognition, motivation, and understanding. L. Erlbaum Associates. 